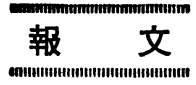

\title{
沸騰伝熱条件下におけるボイラ蒸発管のアルカリ腐食*
}

\author{
小若 正 倫** 北村昌章** 中島孝 司**
}

\section{Corrosion of Boiler Tubes under Heat Transfer in Boiling Alkaline Solutions}

\author{
Masamichi Kowaka, Masaaki Kitamura and Takashi Nakajima
}

\begin{abstract}
Some alkaline solutions were boiled in boiler tubes under heat transfer at $350^{\circ} \mathrm{C}$, and corrosion characteristics of the tubes were observed. Local corrosion developed at the lower part of the tubes, and no corrosion was observed in the upper part, owing to the rinsing action of bubbles from the lower part. Sodium hydroxide was the most aggressive among the three reagents tested for the tube surface under the deposit. Corrosion characteristic changed from pitting corrosion to severe general corrosion with increasing thickness of the deposit. Sodium phosphate seemed to be least corrosive if it does not thickly precipitate on the wall.
\end{abstract}

The mill-scale and the rust had almost no influence on corrosion by themselves. It was, however, important for corrosion that they detached from the wall and deposited at the stagnant spots, where local corrosion occurred under the heat transfer. The surface scratch had no effect on corrosion in sodium phosphate solution and also in potassium phosphate solution. In case of sodium hydroxide solution, local corrosion occurred at the scratches under the heat transfer when their depths were more than $0.3 \mathrm{~mm}$. The deposit formed by hideout of sodium phosphate solution was also examined.

\section{1. 舶言}

昭和 33 年ころを中心として, わが国の当時の新鋭火 力発電ボイラが相ついで類似の腐食事故を起こした。そ の原因と対策が検討されアルカリ腐食であると断定され た ${ }^{1 \sim 4)}$ 。筆者らも静的試験を行なって高温高濃度フルカ リによる軟鋼の腐食が激しいものであるという結果を得 た5)。その他の研究例も大低オートクレーブによる静的 環境における浸漬試験が多く, その結果からアルカリ腐 食が論ぜられたが, 実際のボイラ蒸発管では伝熱, 沸騰 といら環境下にあるため, アルカリ腐食を論ずるとき, できるだけ実際の条件に近い環境で実験を行なう必要が あると考元て, 伝熱, 沸騰条件を設定できる実験装置を 考案し、それによって各種のフルカリによる鋼管の腐食 状況を考察した結果を報告する。

\section{2. 実験装置と実験方法}

图1に示したように $50.8 \phi \times 1,500 l(\mathrm{~mm})$ の鋼管の 上部に水冷ジャケットを取りつけたもので, 蒸発した水 蒸気を全量凝縮し得るようにし，これを $400 \mathrm{~mm}$ の加 熱帯を有するエレマ师に抻入して加熱した。加熱部でて ルカリ水溶液の沸騰が起こるるので, 実験後この部分を

\footnotetext{
* 昭和 39 年 10 月13日 第 11 回富食防食討蜦会(仙台), 昭和 39 年 10 月 30 日学振第 97 委員会会讙 (京都), 昭和 40 年 11 月 11 日 第 12 回嚅食防食討論会 (名古屋) 亿て発表

** 住友金属工業(株) 中央技術研究所（兵庫県尼崎市西長洲本通）
}

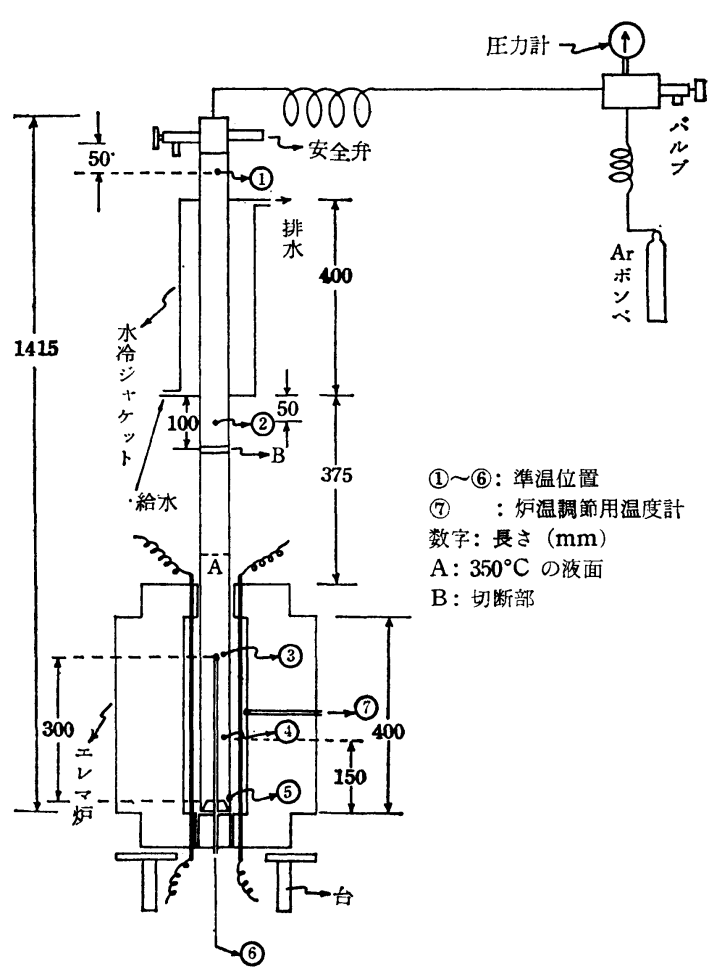

図 1 ボィラ蒸発管腐食実験装置 
縦割りして腐食状況を観察することができる。実験方法 は，管の上部からアルカリを約 $400 \mathrm{cc}$ 注入してから(昇 温時の液面が図 1 のA）各部に熱電対を点溶接して炉内 に揮入する。水冷ジャケットに泠却水を通してから $\mathrm{Ar}$ ガスで約 $90 \mathrm{~atm}$ 加压し昇温すると温度上昇とともに圧 力が上昇するが管内液温（図中(6) が試験温度になるよ うに圧力を調節すると, その圧力を水蒸気压とする液温 でアルカリは沸騰状態を継続する。一定時間試験後図 1 のB部より切断して管を縦割りし腐食状況を観察する。

\section{3. アルカリの種類，濃度の影響}

\section{1 実験条件}

a) 濃度, 液温: $2 \%-350^{\circ} \mathrm{C} \quad 10 \%-330^{\circ} \mathrm{C}$

b) 炉調節温度: $730^{\circ} \mathrm{C}$

c) アルカリの種類: $\mathrm{Na}_{3} \mathrm{PO}_{4}, \mathrm{NaOH}, \mathrm{K}_{3} \mathrm{PO}_{4}$

d) 試験時間: 100 時問

\section{$3 \cdot 2$ 実験結果}

以上の条件で行なった結果を図 2 , 図 3 に示す。いず れも腐食後酸洗により脱スケールしたもので，特徵的な 腐食状態は炉の下部に現われるので管底部付近のみを拡

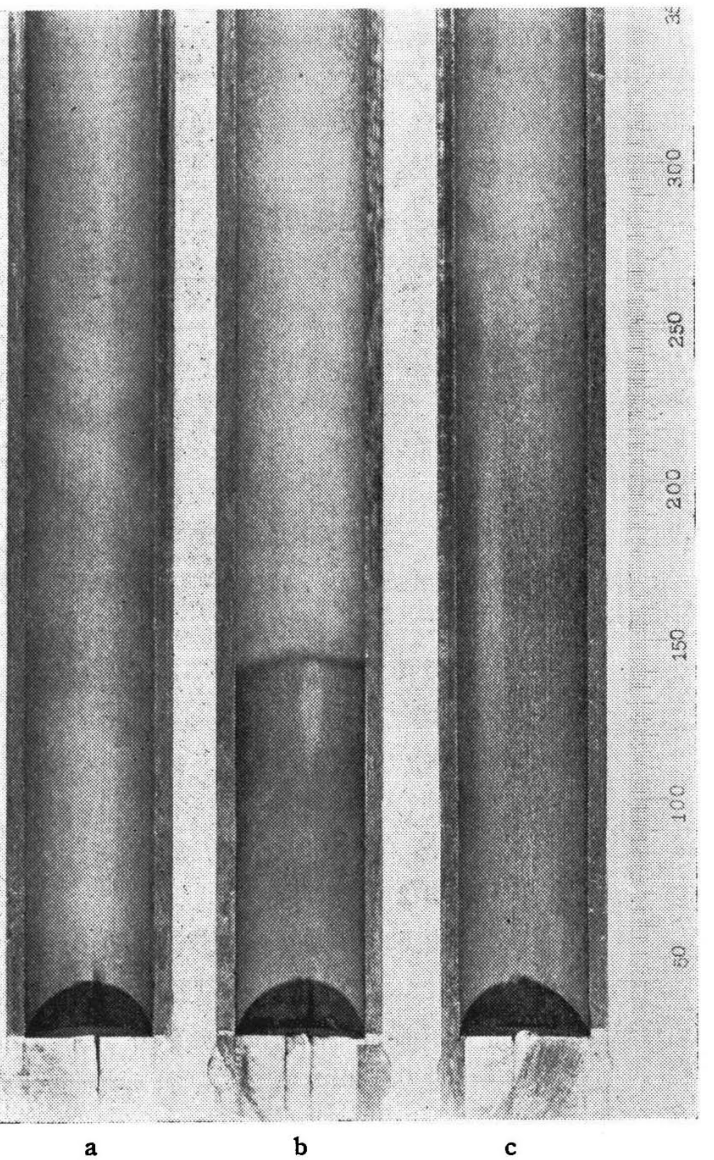

図 2 各種厂ルカリによる腐食状況 浱度: $2 \%$, 液温: $350^{\circ} \mathrm{C}$, 炬温: $730^{\circ} \mathrm{C}$, 時間: $100 \mathrm{hr}$ a: $\mathrm{Na}_{3} \mathrm{PO}_{4}, \mathrm{~b}: \mathrm{NaOH}, \mathrm{c}: \mathrm{K}_{3} \mathrm{PO}_{4}$

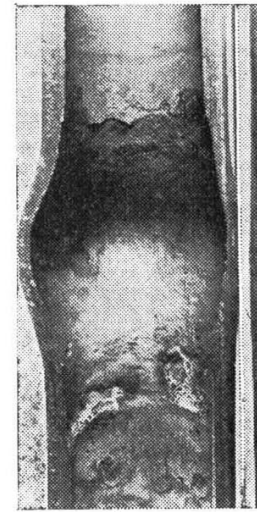

a

娄

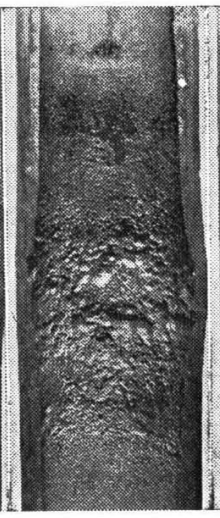

b

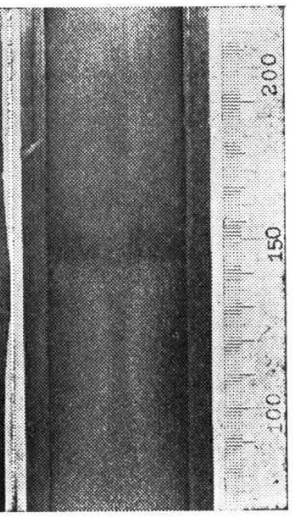

c
䈨度: $10 \%$, 液温: $330^{\circ} \mathrm{C}$, 炕温: $730^{\circ} \mathrm{C}$, 時間: $100 \mathrm{hr}$ a: $\mathrm{Na}_{3} \mathrm{PO}_{4}$, b: $\mathrm{NaOH}$, c: $\mathrm{K}_{3} \mathrm{PO}_{4}$

大して示す。図の右側のスケールは管底（炉底）からの 高さを示す。

\subsubsection{2\% アルカリ}

$\mathrm{Na}_{3} \mathrm{PO}_{4}$ による腐食は非常にきれいな表面で外見上腐 食の跡は全く認められず最も軽微である。 $\mathrm{NaOH}$ では 管底より $130 \mathrm{~mm}$ 付近に肌荒れがあり 孔食の兆候を示 している。 $\mathrm{K}_{3} \mathrm{PO}_{4}$ は肌荒れが激しく, 細かい針状の孔 食を起こす。この条件では, いずれも腐食生成物は非常 に少ない。これらの状態を図 2 に示す。

\subsubsection{0\% アルカリ}

$\mathrm{Na}_{3} \mathrm{PO}_{4}$ では実験開始直後から管壁温度は急激な上昇 を示し, 20 時間で $350^{\circ} \mathrm{C}$ から $440^{\circ} \mathrm{C}$ になった。これは $\mathrm{Na}_{3} \mathrm{PO}_{4}$ が高温で析出（ハイドアウト）したための熱伝 達不良による過熱の結果で，そのため腐食が激しく40 時間で龟裂膨出した。管径は $65 \mathrm{~mm} \phi$ に膨出し, そこ に多量の腐食生成物 $\left(\mathrm{Fe}_{3} \mathrm{O}_{4}\right)$ が付着しており, 酸洗後の 表面は均一な全面腐食である。 $\mathrm{NaOH}$ も実験開始後 50 時間より管壁の温度上昇が激しくなり 70 時間で黾裂が 発生した。腐食は管底より $70 \sim 200 \mathrm{~mm}$ 及えでおり， いずれも腐食生成物の下に起こっている。その両端部は 細かい孔食状の肌荒れを呈しているが中程は著しいあば た状の全面不均等凹凹腐食である6)。ここには特に黒色 腐食生成物の堆積が多く, 局部過熱と濃縮による腐食で あるが，この凹凹および孔食が $\mathrm{NaOH}$ による腐食生成 物下の腐食の特徵である。 $\mathrm{K}_{3} \mathrm{PO}_{4}$ は予想に反して非常 に腐食は軽微であったが酸洗するとスケールの下は細か い針状の孔食で著しい肌荒れを起こしている。これは $\mathrm{K}_{3} \mathrm{PO}_{4}$ による腐食の特徵である。

\section{4. 伝熱量の影響}

次にエレマ炉の調節温度を変化させることにより，伝 熱量を增大させ，2\% アルカリによる腐食状況を観察し 
表 1 伝熱量 $\left(\mathrm{kcal} / \mathrm{m}^{2} \cdot \mathrm{hr}\right)$

\begin{tabular}{c|r|r|r|r}
\hline \hline \multicolumn{2}{c|}{ 温 度 $\left({ }^{\circ} \mathrm{C}\right)$} & \multicolumn{3}{|c}{ フ } \\
\cline { 4 - 5 } 液 温 & 炻 温 & $\mathrm{Na}_{3} \mathrm{PO}_{4}$ & $\mathrm{NaOH}$ & $\mathrm{K}_{3} \mathrm{PO}_{4}$ \\
\hline \multirow{2}{*}{350} & 730 & 29,700 & 29,900 & 28,400 \\
& 930 & 65,200 & 70,200 & 75,300 \\
& 1,030 & 98,200 & 111,500 & 92,000 \\
\hline
\end{tabular}

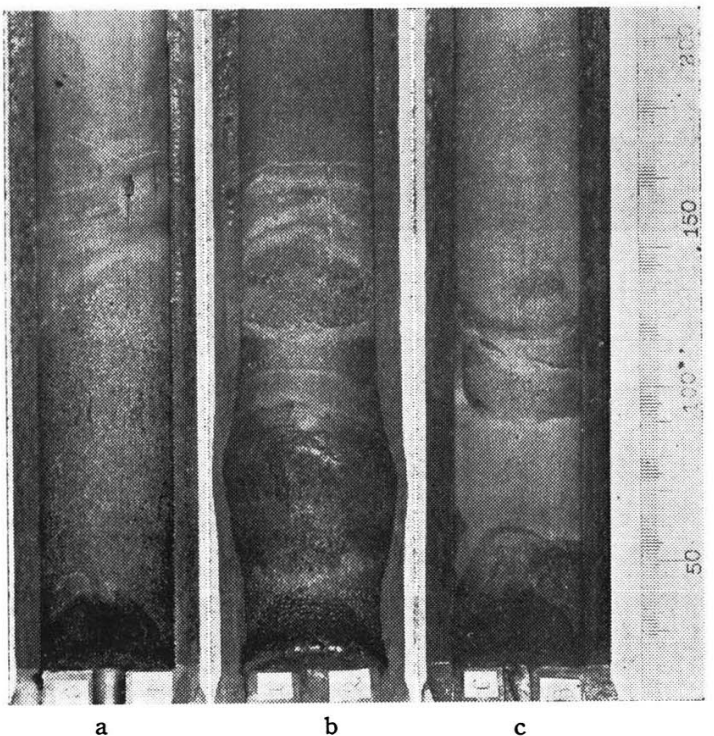

図 4 炉温 $1,030^{\circ} \mathrm{C}$ 調節の場合の腐食状況

濃度: $2 \%$, 液温: $350^{\circ} \mathrm{C}$, 時間: $100 \mathrm{hr}$ a: $\mathrm{Na}_{3} \mathrm{PO}_{4}$, b: $\mathrm{NaOH}$, c: $\mathrm{K}_{3} \mathrm{PO}_{4}$

た。各条件における伝熱量を表 1 に示し，特に炉温 $1,030^{\circ} \mathrm{C}$ の場合の腐食状況を図 4 に示す。伝熱量は上部 ジャケットの泠却水の熱含量変化より求めた。

\section{$4 \cdot 1 \quad \mathrm{Na}_{3} \mathrm{PO}_{4}$}

伝熱量を増大しても顕著な腐食は認められないが管底 部付近に一種の模様が涊められ，これが温度上昇ととも に次第に管底へ移動する。これは $\mathrm{Na}_{3} \mathrm{PO}_{4}$ のハイドフウ

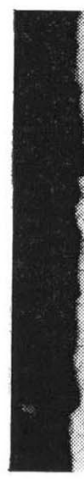

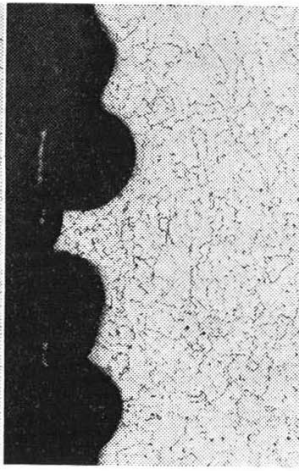

b

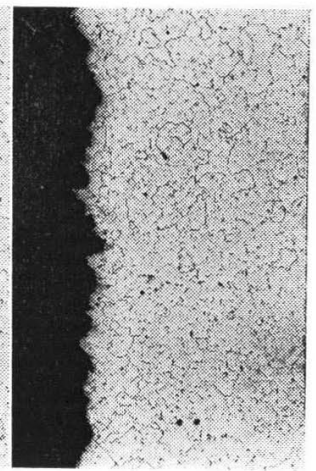

c
図 5 各種厂ルカリによる腐食状況 $(\times 50)$ フルカリ湛度: $2 \%$, 炉温: $930^{\circ} \mathrm{C}$, 位置: 管底より $75 \mathrm{~mm}$ a: $\mathrm{Na}_{3} \mathrm{PO}_{4}$, b: $\mathrm{NaOH}, \quad$ c: $\mathrm{K}_{3} \mathrm{PO}_{4}$
トの下地に起こった軽い腐食の跡と考えられるが，断面 の顕微鏡観察によっても異常は認められない。全般に $\mathrm{Na}_{3} \mathrm{PO}_{4}$ による腐食注 $\mathrm{NaOH}, \mathrm{K}_{3} \mathrm{PO}_{4}$ に比して最を僅 少であり，軽い析出はむしろそれによって防食されるよ うである。

\section{$4.2 \mathrm{NaOH}$}

$730^{\circ} \mathrm{C}$ 調節では軽い孔食の兆候が認められたが，930 ${ }^{\circ} \mathrm{C}$ では腐食スケールの下地に明膫に孔食が認められ， $1,030^{\circ} \mathrm{C}$ になると腐食はますますはげしくなり，腐食生 成物の堆積が多くなり，過熱浱縮が繰り返されて腐食は 加速され，管は亀裂膨出を起こし，下地は凹凸状腐食か らさらに均一な全面腐食になっている。また,これらの 特徵を示寸腐食位置が，加熱温度の増大とともに，次第 に管底部へ移動している。

\section{$4.3 \quad \mathrm{~K}_{3} \mathrm{PO}_{4}$}

腐食生成物の量が伝熱量の増大とともに多くなり，肌 荒れの位置も次第に管底部に移動する。 $\mathrm{K}_{3} \mathrm{PO}_{4}$ による腐 食生成物は $\mathrm{NaOH}$ によるそれと異なって㕷離落下しや すいため管底に落下堆積し，そのため管底で法伝熱不良 になって局部過熱を起こして腐食し，若干肉薄になって いるのが観察される。各種アルカリの $930^{\circ} \mathrm{C}$ 調節にお ける腐食状況を図 5 に示す。各アルカリによる腐食の特 徴がよく現われている。

\section{5. 表面症の影響}

ボイラ蒸発管は高い寸法精度が要求されるため, 冷間 仕上鋼管が使用され，その表面疪が鋼管の強度に影響す るため厳重に検査されるが，その腐食の影響はほとえど 解明されていない。一般には隙間が存在することによる 局部濃縮が考光られているが，いかなる表面でも粗らさ を有しないものはない。どの程度の疵ならば許容できる かという問題になる。ここでは表面疵の影響を調べるた め, 約 $300 \mathrm{~mm}$ 長さにわたって管周 4 力所に断面三角 形状の溝を作ったものについて行なった。

\section{1 実験条件}
a) アルカリ濃度：2\%
b) 疵の深さ: $0.1,0.3,0.5 \mathrm{~mm}$ ( $\mathrm{V}$ 溝状)
c) 実験時間：100，300 時間

\section{$5 \cdot 2$ 実験結果}

$0.5 \mathrm{~mm}$ 疵の腐食状況を图 6,7 に 示し, 疪の形状の変化を知るために各 部の断面の顕微鏡写真を図 8,9 亿示 す。 $0.1 \mathrm{~mm}$ 疵ではいずれも疵部が腐 食に影響を与えたような状況は認めら れず, $\mathrm{NaOH}$ においても疵とは無関 係に孔食が発生しており $\mathrm{K}_{3} \mathrm{PO}_{4}$ の場 合も均一な肌荒れを起こしている。 


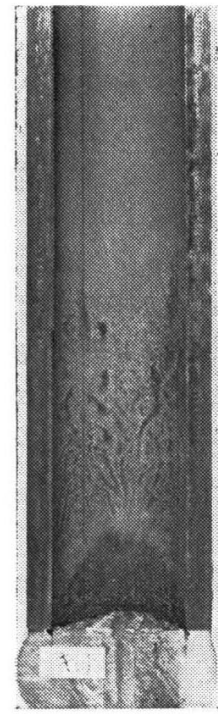

a

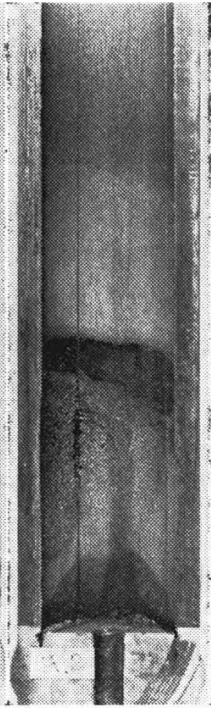

b

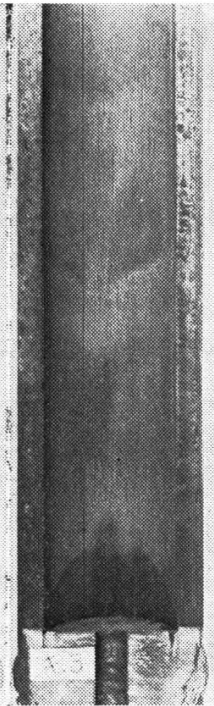

c

図 6 面表疵の影響 (1)

疪の深さ： $0.5 \mathrm{~mm}$, 時間: $100 \mathrm{hr}$ a: $\mathrm{Na}_{3} \mathrm{PO}_{4}$, b: $\mathrm{NaOH}$, c: $\mathrm{K}_{3} \mathrm{PO}_{4}$

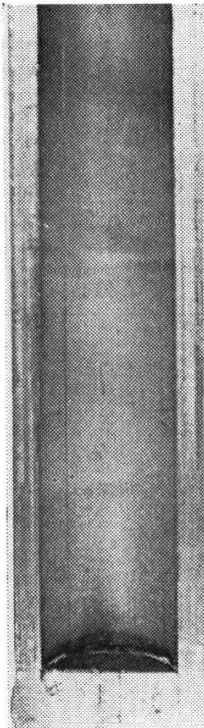

a

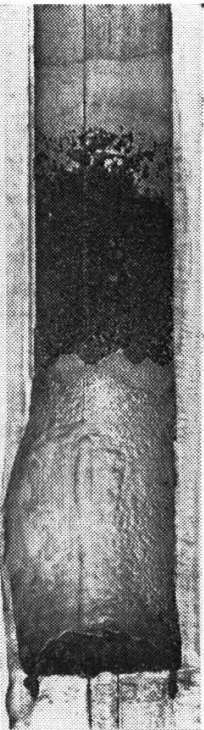

b

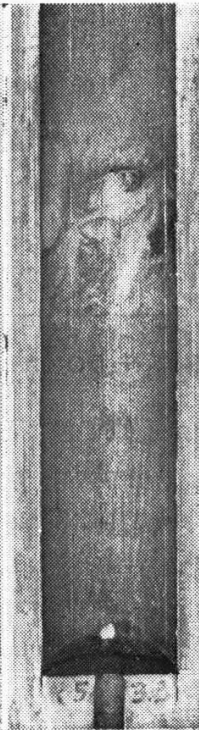

図 7 表面瘷の影響 (2) 症の深さ: $0.5 \mathrm{~mm}$, 時間: $300 \mathrm{hr}$ a: $\mathrm{Na} \mathrm{PO}_{4}$, b: $\mathrm{NaOH}, \quad$ : $: \mathrm{K}_{3} \mathrm{PO}_{4}$

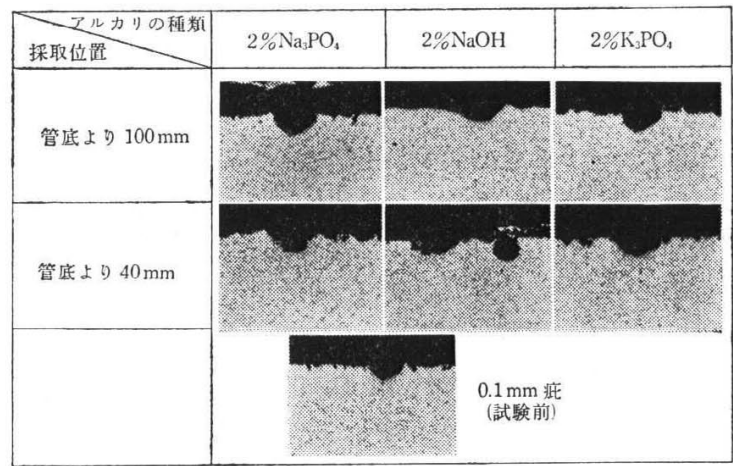

$\times 20$

図 $80.1 \mathrm{~mm}$ 疵部の腐食状況 $\left(350^{\circ} \mathrm{C} \times 300 \mathrm{hr}\right)$ て約 $30 \mathrm{~mm}$ 幅で発錆させた。結果の図は省略したが， 腐食後のものは, 発錆させた位置がやっとわか る程度に跡形があるだけで, 赤錆の下地, 赤錆 とミルスケールの境界線の所にはなえら異常腐 食がないことが顕微鏡観察からも認められた。 その他ミルスケールのまま, およびミルスケー ルの一部酸洗して脱スケールしたものも,なん ら特異な現象は涊められない。腐食後これらの 赤錆は全く存在が認められず，静止オートクレ ーブによる亦錆が昇温によって $\mathrm{Fe}_{3} \mathrm{O}_{4}$ に変質 し, 非常に剶離しやすい状態になった結果から 考えて, 沸騰条件下では変質した赫がすべて 管壁から剶離したものと考えられる。

\section{7. $\mathrm{Na}_{3} \mathrm{PO}_{4}$ のハイドアウト（析出）物質}

$\mathrm{Na}_{3} \mathrm{PO}_{4}$ は水に対する溶解度が $120^{\circ} \mathrm{C}$ を境として温度

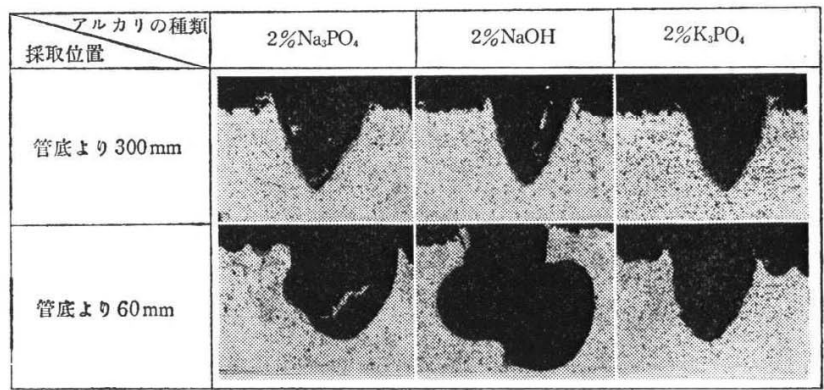

図 $90.5 \mathrm{~mm}$ 㾟部の腐食状況 $\left(350^{\circ} \mathrm{C} \times 100 \mathrm{hr}\right)$

とともに減少するので7)，ボイラの局部過熱部で析出す る。この析出物質について, Schroeder らは $215^{\circ} \mathrm{C}$ 以 上では無水の $\mathrm{Na}_{3} \mathrm{PO}_{4}$ と考え7), F. G. Straub は $\mathrm{Na}_{3}$. 
表 $210 \% \quad \mathrm{Na}_{3} \mathrm{PO}_{4}$ 水溶液からの析出物質

\begin{tabular}{|c|c|c|c|c|}
\hline Run No. & 1 & 2 & 3 & 4 \\
\hline 温度 $\left({ }^{\circ} \mathrm{C}\right)$ & 300 & 300 & 350 & 350 \\
\hline 抜取液の $\mathrm{pH}$ & 12.60 & 12.70 & 12.50 & 12.69 \\
\hline $\begin{array}{l}\text { X線回折によ } \\
\text { 百同定 }\end{array}$ & $\begin{array}{l}\mathrm{Na}_{2} \mathrm{HPO}_{4} \cdot \\
2 \mathrm{H}_{2} \mathrm{O}^{* 1}\end{array}$ & $\begin{array}{l}\mathrm{Na}_{3} \mathrm{PO}_{4} \cdot 12 \mathrm{H}_{2} \mathrm{O}^{* 2} \\
+\mathrm{Na}_{2} \mathrm{HPO}_{4} \cdot 2 \mathrm{H}_{2} \mathrm{O} \\
\end{array}$ & 同左 & 同左 \\
\hline \begin{tabular}{l|l} 
华学分 & $\mathrm{Na}$ \\
析(\%) & $\mathrm{P}$
\end{tabular} & $\begin{array}{l}28.0 \\
15.5\end{array}$ & \begin{tabular}{|l|}
25.0 \\
13.4 \\
\end{tabular} & $\begin{array}{l}23.0 \\
12.9\end{array}$ & $\begin{array}{l}25.0 \\
13.1\end{array}$ \\
\hline $\begin{array}{l}\mathrm{Na/P} \\
(\text { 原子比) }\end{array}$ & 2.43 & 2.51 & 2.40 & 2.57 \\
\hline
\end{tabular}

*1 ASTM カードに一致する

*2 原料の $\mathrm{Na}_{3} \mathrm{PO}_{4} \cdot 12 \mathrm{H}_{2} \mathrm{O}$ 飞一致する

$\mathrm{HPO}_{4}$ に近似できるとし, metaphosphate，あるいは pyro-, polyphosphate である可能性もあるとしてい る8)。また, M. I. Ravich らは $\mathrm{Na}_{3} \mathrm{PO}_{4}$ と $\mathrm{Na}_{2} \mathrm{HPO}_{4}$ の複塩であると結論している9)。筆者らはステンレス製 オートクレーブに $10 \% \mathrm{Na}_{3} \mathrm{PO}_{4}$ 水溶液を入れ $300^{\circ} \mathrm{C}$ お よび $350^{\circ} \mathrm{C}$ に昇温後, 液体部分を抜き取り, 析出した 結晶の化学分析ならびにX線回折による同定を行なっ た。その結果を表 2 に示す。これによれば，析出物質は $\mathrm{Na}$ と $\mathrm{P}$ の原子比はほほ 2.5 であり $\mathrm{Na}_{3} \mathrm{PO}_{4}$ として析 出していないことは明らかである。X線回折の結果は複 雑で完全に同定し得なかった。

\section{8. 考察}

各種アルカリによる局部腐食の特徵は随時に報告した がこれらの腐食はエレマ师中で底部に現われ，それは 伝熱量を増大するとますます管底部へ移動し，それより 上部は外見上なんらの腐食も起こしていない。これは管 底部は液の流動が少ないために常に決まった場所からの み沸騰が起こり, 気泡発生部に濃縮層を生じ孔食などを 生じやすいが，上部は管底部から上昇してくる気泡によ って液の攪乱が盛んであるので沸騰によって気泡を生じ 濃縮層を生じても常に熼乱され希釈される。いわゆる rinsing action によって腐食が少ないのであると考えら れる。このことから液の流動の激しい部分では腐食は僅 少であるが, 液の停滯があると, そこに異物質が堆積し たような場合，伝熱下で液の濃縮によって特に激しい腐 食が起こるものと考えられる。この局部腐食は $\mathrm{NaOH}$ によるものが最も激しく，そのスケールが容易に管壁か ら剝離しないのでその下に孔食から全面不均等凹凸腐食 ないし全面連接孔食腐食さらに進えで激しい全面腐食 を起こし管を穿孔する。 $\mathrm{K}_{3} \mathrm{PO}_{4}$ は同一条件では $\mathrm{Na}$. $\mathrm{OH}$ よりも腐食性が大であるが, 腐食生成物はある程度 の厚さ以上になると容易に管壁から制離落下するので, 付着スケールによる伝熱不良, またそれによる過熱濃縮 の度合は $\mathrm{NaOH}$ よりも軽く, 結果的には $\mathrm{NaOH} よ り$ も腐食は軽微である。 $\mathrm{Na}_{3} \mathrm{PO}_{4}$ は著しいハイドフウト （析出）を起こすと, 伝熱不良による過熱のため, 沸騰部 分などの粗い結晶の割目などからアルカリが浸透し過熱 された管壁と反応して. $\mathrm{Fe}_{3} \mathrm{O}_{4}$ を生じ，その蓄積によっ
て，ますます加速されることになる。ところが $\mathrm{Na}_{3} \mathrm{PO}_{4}$ 水溶液の高温における析出は $\mathrm{Na}$ と $\mathrm{P}$ との比が約 2.5 であるから水側の水酸イオンは過剩となる。そのときの 腐食は $\mathrm{NaOH}$ と類似の状態をとるものと考えられる。 しかし軽い析出はむしろ腐食を抑制し，実験を行なった アルカリの中では最も腐食性が小さい。3\% $\mathrm{NaCl}$ 水で 発錆させたもの, および製管時のミルスケールも腐食に 悪い影響を示さない。赤錆は高温で鉄との接触下で变質 して利離しやすくなるので, その他の固型物も含めて流 動の悪い部分に堆積して, その下に起こる濃縮に基づく 局部腐食の方が重要である。ミルスケールも実際のボイ ラで別離して局部的に堆積しそこに局部腐食を起こすと いう報告もある10)。

三角形状の疵は $\mathrm{Na}_{3} \mathrm{PO}_{4}, \mathrm{~K}_{3} \mathrm{PO}_{4}$ によっては, そこが 腐食の起点とならないが, $0.3 \mathrm{~mm}$ 以上の深さでは, $\mathrm{NaOH}$ によっては局部腐食の起点となる。しかし疵の 形状によっては, より浅い疵でも $\mathrm{NaOH}$ によって腐食 の起点となることが考えられる。もっと細い製管疵に対 しても, $\mathrm{Na}_{3} \mathrm{PO}_{4}$ に対しては全く影響しないことが認め られている11)。

\section{9. 結 論}

伝熱沸騰条件が設定できる装置を考案し，各種のアル カリ水溶液による鋼管の腐食状態の特徵を観察した。

1) $\mathrm{Na}_{3} \mathrm{PO}_{4}, \mathrm{NaOH}, \mathrm{K}_{3} \mathrm{PO}_{4}$ のうち最も腐食性の激 しいのは $\mathrm{NaOH}$ であり，極端なハイドアウトによる伝 熱不良がなければ $\mathrm{Na}_{3} \mathrm{PO}_{4}$ による腐食が最も軽微であ り，軽い析出によってむしろ鋼管は保護される。

2) 水の流動条件の悪い部分では，そこから局部腐食 が発生しやすく，そのとき $\mathrm{NaOH}$ による腐食は，その 腐食生成物が容易に管壁から刹離しないのでその下地に 孔食から全面腐食へ進む激しい局部腐食をもたらす。

3）表面疵は $\mathrm{Na}_{3} \mathrm{PO}_{4} ， \mathrm{~K}_{3} \mathrm{PO}_{4}$ による腐食に対しては 覀い影響はないが, $\mathrm{NaOH}$ に対しては $0.3 \mathrm{~mm}$ 以上深 さのV型溝があるとき，そこが局部腐食の起点になる。 しかし疵の形状によって疵の許容深さは変わるであろ 亏。

4）赤錆, ミルスケールはそれ自体が腐食の起点にな ることはないが，それらが水の流動下で涂離して流れ， 水の流動の悪い所に堆積すると，そこに伝熱下で局部腐 食をもたらすものと考察した。

5) $\mathrm{Na}_{3} \mathrm{PO}_{4}$ 水溶液の高温における析出物質はその原 子比 $\mathrm{Na} / \mathrm{P}$ が約 2.5 であり, それによって水側にはフ リーフルカリが過剩になると考察した。

（昭和 40 年 11 月 29 日受理）

\section{引用文 献}

1）電力中研伎研報（No. 化学 59009）（1960）

2）黒沢辰雄：用水と廃水, 3, 653〜62（1962）

3）新三黄重工技報，3，No. 1，28 35（1961） 
4）福井三郎，厚川麻須美：三菱造船技報 No. 5 (1962)

5) 小若正倫, 北村目章：第 53 回日本金属学会(名古屋)飞て発表

6) 日本石油学会：㻤食形熊写真集（1962）

7) W.C. Schroeder, A. A. Berk \& A. Gabriel: J. Am. Chem. Soc., 59, 1783 (1937)

8) F. G. Straub: Trans. ASME, 479 89 (1950)
9) M.I. Ravich, et al.: Izvest. Sektora Fiz.-Khim. Anal. Inst. Obshches i Neorg. Khim. Akad. Nauk SSSR, 26, 248 58 (1955)

10) R. Vincotte: Werks. Korr., 13 535 38 (1962)

11）小若正倫, 北村冒章, 中島孝司：昭和 40 年 11 月 11 日 第 12 回罂 食防食討論会(名古屋)で発表

\section{学振腐蝕防止第 97 委員会会議（昭和 40 年 9 月 28 日）講演概要}

（1）腐食性その他の環境中での疲れ（第 2 回）

東京大学生産技術研究所 北川英夫氏

前回 ( 7 月 28 日) の報告に引きつづき, 今回は腐食疲 れを中心とした環境疲れ機構に関する諸研究結果を次の ごとく分類して説明した。

（1）腐食疲れ機構の研究における共通事項，(2) 腐食 欠陌の切欠き作用, (3) き裂材としての扱い，(4) 腐食 効果 $k$ の導入, (5) 保護膜の電気化学的挙動, (6) その 他の解釈。以上各研究方法につき, それぞれ, 実験方法 の特徵, 新しく提案された諸概念, 導かれた法則の一部, 提案された方法により解析が可能な諸特性を説明した。 特に (3) 項については, (a) 平均応力の影響の解析, (b) 腐 食中断の影響の解析を例にとって最近の研究結果をスラ イドを用いて報告した。

\section{（2）ハイナック新製品“HINAC COAT T”につ} いて

\section{日本鋼管技術研究所 滝口周一郎氏}

米国の Pennsalt Chemicals Corp. と技術提携をした 從来のハイナックの種類，用途などを説明した後，日本 鋼管KKが独自で開発した罐材用ハイナック新製品, “HINAC COAT T”について，その 2 年間にわたる 研究経過，特性，用途などを述べ，次に発明品 “HINAC $\operatorname{COAT} \mathrm{T} ”$ と国内の主要な競合品 2 種, ブリキ 2 種お よび従来のハイナック I との性能比較試験として, 加工 性試験, 塗装および印刷性試験, 耐食性試験, 而薬品性 試験，耐洗剂性実罐試験，および耐油性実嚄試験の結果 を紹介し，その優秀性を強調した。Tinless 罐時代の製 罐材料として, 近い将来に市場を席巻することは確実 で，国内はもちろん，海外への輸出も相当伸長するであ， ろう。

(3) Studies on Atmospheric Corrosion in National Metallurgical Laboratory, Jamshedpur, India.

K.P. Mukherji 氏

Enormous losses occurring through the corrosion of metals are great concern of the world today.
The loss through the ravages of corrosion in India has been estimated by the corrosion technologists to be in the order of 150 crores of rupees per year. The Nationa1 Metallurgical Laboratory has taken determined approach for understanding the mechanism of corrosion by performing both laboratory and field tests. The studies on atmospheric corrosion of metals is one such objective. Our findings based on exposure tests and laboratory studies can be summerised as follows:

1) Atmospheric pollution, relative humidity, state of exposure, composition of the material have been shown to have great influence on corrosion.

2) Comparative corrosion rates of different metals showed the order of mild steel, low alloy steel, zinc, copper, brass, nickel, and monel, the rate being maximum for mild steel and least for monel.

3) Detailed studies on chemical, electrochemical and physical analysis showed that the characteristics of the rust change considerabily with the period of exposure.

4) On atmospheric galvanic corrosion studies the result obtained with different couples did not show expected result as per galvanic series. Of all the metals tested zinc and aluminum showed protection to mild steel.

5) Reasons for withstanding corrosion of ancient Delhi Iron Pillar and Iron Beam of Konarak Temple are attributed to the existance of outer mixer of slag, oxides, etc., and their envelope within and around the metal which afford considerable resistance by drastically reducing the number of breakdown areas where corrosion attack could be initiated. 